DOI: https://doi.org/10.32839/2304-5809/2021-4-92-11

УДК 37.01/.09

Лаврова А.В.

ВСП «Торговельно-економічний фраховий коледж Київського національного торговельно-економічного університету»

\title{
МЕТОД ПРОЄКТІВ НА УРОКАХ УКРАЇНСЬКОЇ ЛІТЕРАТУРИ В СТАРШИХ КЛАСАХ
}

Анотація. У статті розкрито сутність поняття «метод проєктів», розглянуто тлумачення дефініції «метод проектів» у роботах українських науковців та обгрунтовано доцільність використання цього методу школярами. Здійснено аналіз етапів створення проєктів (організаційний, корекщійний та презентаційний). Окреслено роль вчителя як консультанта та модель спілкування між учителем та учнями під час підготовки проєктів. Наведено приклади проєктних завдань з української літератури для учнів старших класів, описано які саме аспекти можуть зацікавити учнів у контексті вивчення української літератури. Розкрито роль кінцевого продукту, що є результатом науково-пошукової проектної діяльності учнів. Висвітлено вміння і навички, які учень може здобути та розвинути завдяки підготовці проектів з української літератури, а саме: знаходити та виділяти необхідну інформацію, вміння адекватно сприймати критику, вміння працювати в команді, презентувати результати своєї діяльності та ін .

Ключові слова: проєкт, міжпредметні проєкти, роль керівника проєкту, сучасна концепція літературної освіти.

Lavrova Alona

College of Trade and Economics

Kyiv National University of Trade and Economics

\section{METHOD OF PROJECTS IN LESSONS OF UKRAINIAN LITERATURE IN SENIOR CLASSES}

Summary. The article explains the interpretation of the definition of "project method" in the works of Ukrainian scientists and substantiates the feasibility of using this method by students. The expediency and specificity of using the proposed method in lessons of Ukrainian literature in high school are theoretically substantiated. Creating a model of project work on teaching Ukrainian literature in senior classes aims to become an alternative to the traditionally established basic pedagogical methods, under the conditions of which the leading role of the teacher and his classroom activity is preferred, and create conditions for the leading role to belong to the student as an individual with their preferences and ideas. The article presents the general scheme of project creation, outlines the stages and methods of educational activities in the process of their preparation. The role of the teacher as a consultant and the model of communication between teacher and students in the process of project modeling are highlighted. The skills that a student can acquire and develop through the preparation of projects on Ukrainian literature, namely: to find and highlight the necessary information, the ability to adequately accept criticism, the ability to work in a team, generate and implement new ideas, present the results of their activities and others. Examples of project tasks in Ukrainian literature for high school students are given, it is described which aspects may be of interest to students in the context of studying Ukrainian literature, as recently there is a tendency to reduce students' interest in reading Ukrainian literature. The role of the final product, which is the result of research and project activities of students, is revealed. The final products of the project activity in the lessons of Ukrainian literature can be a presentation, a dictionary, a book of illustrations, comics, etc. The main attention is focused on the authors of the program of literary works (grades 10-11): M. Kotsyubynsky, I. Franko, L. Ukrainka, P. Tychyna, V. Pidmohylny, M. Khvylovy, Y. Yanovsky, I. Bagryany, V. Stus etc.

Keywords: project, interdisciplinary projects, the role of the project manager, the modern concept of literary education.

Постановка проблеми. Сучасна концепція шкільної літературної освіти визначає нові ролі як для вчителя, так і для учнів. Нова освітня парадигма ставить у центр навчальнопізнавального процесу саме учня, його потреби та інтереси, які слід задовольнити 3 огляду на його інтелектуальне, емоційне та соціальне становлення та зростання як особистості.

Українська література - один із ключових шкільних предметів, вивчення якого передбачає не лише отримання базових знань, а й формування гуманістичного світогляду, розвиток естетичного смаку, любові та поваги до української культури, історії.

У сучасній школі спостерігається тенденція зниження інтересу учнів до читання української літератури, що обумовлено низкою причин: одноманітні уроки і домашні завдання, примус, авто- ритарне спілкування вчителя з учнями та багато інших. Саме тому сучасний вчитель все частіше звертається до інтерактивних методів навчання.

Аналіз останніх досліджень і публікацій. Власне педагогічне проєктування досліджувалося плеядою науковців, серед яких В. Безруков, Е. Заїр-Бек, О. Киричук, І. Підласий, Н. Суртаєва, Ю. Чернова, В. Юсупова. На важливості застосування методу проєктів у навчанні акцентують такі дослідники, як О. Коберник, С. Кримський, І. Єрмаков, Н. Бібік, Л. Ващенко, О. Локшина, О. Овчарук, О. Коберник, Л. Цимбалару, Г. Ісаєва та ін.

Виділення не вирішених раніше частин загальної проблеми. У науковій літературі схарактеризовано проєктний метод навчання, але $€$ необхідність описати можливі варіанти його застосування при вивченні української літератури 
у старших класах. Це сприятиме пожвавленню освітнього процесу та підвищенню інтересу учнів до вивчення української літератури.

Мета статті - розкрити сутність понять «проєкт», «метод проєктів», пояснити значущість застосування цього методу в навчально-виховній діяльності, розкрити можливості використання методу проєктів на уроках української літератури у 10-11 класах.

Виклад основного матеріалу. Серед інтерактивних методів навчання останніми роками набув популярності метод проєктів. В “Українському педагогічному словнику" подано визначення, згідно з яким метод проєктів є організацією навчання, “за якою учні набувають знань i навичок у процесі планування й виконання практичних завдань-проєктів" [3, с. 205].

Розглянемо тлумачення дефініції «метод проєктів» у роботах вітчизняних науковців:

- систематична форма організащії діяльності у взаємозв'язку їі теоретичних і практичних аспектів (С. Б. Кримський) [8, с. 13];

- процес який розвиває проєктувальні навички його учасників, уміння орієнтуватися в інфрормаційному просторі, використовувати набуті знання на практиці, фрормуе вміння самостійно конструювати власну діяльність (Л. С. Василевська) [2, с. 2];

- освітня технологія, яка спрямована на здобуття учнями знань у тісному зв'язку з реальною життевою практикою, формування в них умінь і навичок завдяки системній організації проблемно-орієнтованого навчального пошуку (Г. М. Ісаєва) [5, с. 3];

- самостійний вид діяльності, що передбачає наявність такого етапу, як прогнозування (спеціально організоване дослідження, спрямоване на отримання інформації про розвиток об'єкта) (А. Д. Цимбалару) [10, с. 30-35];

- інноваційна форма організації освітнього середовища, в основі якої лежить комплексний характер діяльності тимчасового колективу спеціалістів в умовах активної взаємодії 3 навколишнім середовищем (Н. М. Бібік, Л. С. Ващенко, О. І. Локшина, О. В. Овчарук) [1, с. 5-7];

- один із важливих компонентів освітнього процесу, завдяки якому учні під час роботи отримують можливість працювати в умовах свободи, вчаться формулювати і вирішувати проблеми, використовувати інформаційні ресурси, здійснювати самоосвіту, працювати в умовах діалогу (Н. Тищенко) [9, с. 45].

Із цих дефініцій можемо зробити висновок, що проєкт - це творча робота, яка враховуе як теоретичне, так і практичне навчання, передбачає глибину знань, можливість аналізу ситуащій, використання моделі роботи в команді, спрямованої на досягнення певної мети. Метод проєктів навчає учнів особистій відповідальності та самодисципліні, фрормуе навички прийняття рішень, самооцінювання, створюе відчуття приналежності, розвиває ініціативність, допитливість та креативність, готовність служити інтересам громади та громадянській відповідальності. Відпрацьовані в процесі роботи над проєктом вміння учень зможе використовувати у подальшому житті $[6$, с. 6].

Будь-який проєкт передбачає перебіг певної кількості фраз (стадій, етапів). Умовно можна ви- ділити три етапи створення проєкту: підготовчий, корекційний та презентаційний [7, с. 16].

Під час підготовчого етапу учень обирає тему та проблему, яка йому цікава; спілкуеться з керівником щодо своїх ідей та способів їх реалізації. Вчитель при цьму не дає готових рішень, а лише скеровуе до джерел інформації, яка буде корисна учням під час підготовки їх проєктів. Оскільки процес навчання, спрямований на формування позитивної мотивації, він повинен характеризуватися відходом від авторитарного спілкування і сприяти розвитку пізнавальних інтересів, активності, самостійності школярів.

Вже на підготовчому етапі в автора проєкту формуеться бачення того, яким буде кінцевий продукт його пошукової діяльності: презентація, словник, комікс, доповідь, гра, карта, малюнки, відео тощо.

Наступний етап - корекційний. Учитель разом з учнем переглядає вже готовий продукт і за потреби пропонує щось виправити, змінити або доповнити. Також на цьому етапі обговорюються досягнення поставленої мети та виконання усіх пов'язаних із її досягненням задач. Вчитель дає конструктивний коментар до проєкту, який має бути засобом підтримки: допомагати особистості у визначенні власної позиції, давати поради щодо подальшої роботи, підвищувати самоощінку та самоповагу учнів.

На етапі презентації учень вільно демонструє свій проєкт. Інші учасники освітнього процесу долучаються до обговорення складних питань. Як керівник, вчитель може підготувати питання, що можуть залучити учнів до дискусії щодо розв’язання проблем, порушених у проєкті.

Проекти можуть різнитися за:

- тривалістю: короткотривалі (кілька днів), середньотривалі (місяць), тривалі (кілька місяців);

- кількістю учасників: індивідуальні (виконує один учень) і групові (виконуються колективом); - характером проблеми: монопредметні (проблема розкривається в межах одного навчального предмета) та міжпредметні (проблема належить до двох або більше галузей знань) [6, с. 17].

Під час створення проєктів з української літератури важливо, щоб в учнів була налагоджена комунікація 3 керівником, який не дає готових рішень, а лише допомагає в оформленні творчого потенціалу учнів. Керівниками проєктів можуть бути вчителі різних предметів. Наприклад, до вивчення п'єси Миколи Куліша «Мина Мазайло» можна долучити вчителів історії та правознавства, розглянути проблему різниці у ставленні до української мови сьогодні та на початку XX ст. в історичному зрізі, як мовне питання було висвітлено на законодавчому рівні тоді і зараз.

Проєктне навчання, що здійснюеться в рамках класно-урочної системи, передбачає самостійність учнів у виборі предмета дослідження, способів пошукової роботи, усвідомлення практичного значення здобутих знань. Під час роботи 3 начальним проєктом, яка вибудовується як науково-пошукова, учень стає активним учасником життя і має цільову установку. Робота має для нього практичне значення, адже під час захисту він стверджується як самодостатня творча особистість, а набутий досвід зможе використати і в майбутньому [5, с. 207-211]. 
Навіть за відсутності бажання вивчати той чи інший літературний твір учнів можна заохотити проблемою, що їм цікава. Так, наприклад, розглядаючи роман Валер'яна Підмогильного «Micто», можна поділити проблему підкорення міста на частини і розділити їх між групами учнів, наприклад: 1) «слава» (що потрібно молодій людині для того, щоб здобути популярність); 2) «гроші» (як Степан Радченко заробляв свої перші гроші, на які кошти він жив, що міг дозволити собі на той час); 3) «дружба» (стосунки з людьми, психологічні бар'ери, вибудувані Степаном Радченком) та ін.

Нині існуе потреба в розробленні завдань проєктного характеру з української літератури, що відповідатимуть сучасним потребам і зацікавленням учнів, для їх активного використання у навчальних закладах України.

Створення моделі проєктної роботи з викладання української літератури у старших класах має на меті подолати пасивність у навчанні за допомогою різних позакласних заходів. Ї̈̈ апробація $е$ альтернативою традиційно встановленим базовим педагогічним методам, за умов використання яких віддаеться перевага провідній ролі вчителя та його аудиторній діяльності. У викладача вже $е$ нова роль - бути консультантом, посередником, співробітником та радником учнів. Він повинен мотивувати, заохочувати учнів, відповідати на їхні запитання: Для чого це потрібно? Як це їм допоможе? Що може бути кінцевим продуктом і для чого він буде використовуватися в майбутньому? У реалізації проєкту роль викладача полягає лише у підтримці учнів та організації процесу навколо його підготовки та представлення кінцевих результатів.

Розглянемо приклади використання проектних завдань на уроках української літератури в старших класах:

- Порівняльна характеристика повісті I. Нечуя-Левицького «Кайдашева сім'я» та серіалу «Спіймати Кайдаша»: спільне та відмінне. Кінцевий продукт: презентація.

- Внутрішній світ героїв роману Панаса Мирного «Хіба ревуть воли, як ясла повні»). Учні аналізують вчинки героїв і пояснюють їх з використанням джерел з психології: підручників, статей. Кінцевий продукт: презентація.

- Сцена 3 вистави «Сучасний Мартин Боруля». Учні обирають сцену з комедії І. Тобілевича, яка, на їх думку, могла б статися в сучасній Україні, пишуть сценарій і розігрують його за ролями. Кінцевий продукт: сценка.

- Звукові образи у новелі «Intermezzo» M. Коцюбинського. Учні виписують звукові образи і цитати з твору, а потім шукають добірку звуків, що передають цитати. Кінцевий продукт: презентація.

- Роль Ольги Кобилянської у феміністичному русі на поч. XX ст. Кінцевий продукт: презентація.

- Проблема еміграції: що потрібно змінити, аби вона припинилися? (за мотивами новели Василя Стефаника «Камінний хрест»). Учні використовують дані статистики, перераховують загальні причини та наслідки еміграції, порівнюють становище ціеї проблеми в історичному зрізі на початку XX ст. і сьогодні. Кінцевий продукт: презентація.

- Постать С. Параджанова в українській культурі. Учні переглядають фільм С. Параджанова
«Тіні забутих предків», фільм «Параджанов», шукають інформацію про режисера, про історію створення фільму за мотивами повісті М. Коцюбинського. Кінцевий продукт: презентація.

- Створення словничка діалектизмів на основі повісті «Тіні забутих предків». Кінцевий продукт: словничок.

- Створення реклами відпочинку на Кононівських полях ( за мотивами новели М. Коцюбинського «Intermezzo»). Кінцевий продукт: презентація/ картинки/ відео.

- Феномен «Розстріляне відродження». Учні шукають інформацію і обирають самостійно, у якому вигляді презентуватимуть свої знання. Кінцевий продукт: презентація/ вибірка літературних творів/ вірш.

- Автобіографічність роману «Майстер корабля» Ю. Яновського. Кінцевий продукт: презентація/доповідь.

- Словник авторських неологізмів П. Тичини (збірка «Сонячні кларнети»). Кінцевий продукт: словник.

- Особистість В. Стуса. Учні готують інформацію про життя поета, переглядають фрільм «Заборонений» і презентують своє бачення творчої особистості В. Стуса. Кінцевий продукт: презентащія/книга ілюстрацій.

- Карта втечі Григорія Многогрішного (за романом «Тигролови» I. Багряного). Учні готують карту, де підписують місця, де відбувалися основні події твору, позначають на карті маршрут Григорія Многогрішного та майора НКВС Медвина. Кінцевий продукт: карта.

- Музичне оздоблення української поезії. Учні готують вибірку пісень українських виконавців із текстами поетів. Кінцевий продукт: відео / презентація.

- Творче тлумачення поезії. Учні можуть підбирати музику, яка найкраще відповідае конкретним віршам, малювати образи, які виникають під час читання поезій, покласти якийсь вірш на музику, створити власну поезію. Кінцевий продукт: презентація / малюнки / пісня / авторська поезія.

- Книга ілюстрацій до твору. Учні займаються пошуком усіх ілюстрацій, знаходять відповідні сцени у творі, добирають цитати, називають ілюстраторів. Кінцевий продукт: книга ілюстрацій.

- Створення коміксів до прочитаних творів. Комікс - графрічно-оповідний жанр, у якому поєднано малярство (карикатуру, послідовність малюнків) і літературу (короткі тексти у вигляді «мовної бульки» чи «хмарки»); серія зображень із короткими текстами, що становлять історію. Кінцевий продукт: книжка з такими малюнками [12].

- Створення мемів до прочитаних творів. Меми зображення гумористичного характеру, які імітують готові продукти культури. Культура інтернет-мемів сьогодні поширена серед молоді, тому таке завдання буде входити в коло інтересів учня. Кінцевий продукт: книжка з картинками/презентація.

- Створення реклами. Учні підбирають продукти, які можна прорекламувати за допомогою сюжетів літературних творів. Кінцевий продукт: відео / презентація / малюнок.

- Екранізації програмних творів з української літератури. Кінцевий продукт: презентація / уривки 3 кінофрільмів. 
Урок літератури має розвивати уяву та творчий потенціал учнів, заохочувати їх до саморозвитку, пробуджувати інтерес до читання книг. Метод проектів дозволяе вчителям урізноманітнювати свою професійну діяльність, використовуючи життево важливі й цікаві для учнів теми. Під час проблемно-пошукової роботи базові знання для учнів стають не метою, а засобом у досягненні навчальної мети. Саме тому такий підхід до навчання найкраще застосовувати для учнів старших класів, які вже мають достатній багаж знань та сформованих умінь [9, с. 42-48].

Висновки і пропозиції. Впровадження методу проєктів у освітній процес - складна, але цікава справа, яка спонукае до інтелектуальної діяльності, відмінною особливістю якої є перспективна орієнтація, практично спрямоване дослідження. Метод проєктів на уроках української літератури у 10-11-х класах спонукає до всебічного особистісного розвитку учнів, навчае їх працювати в команді і брати на себе відповідальність, при цьому дозволяе здобути грунтовні знання з української літератури.

Більшість вчителів вже ознайомлені з методом проєктів і активно використовуе його на своїх заняттях. Однак сьогодні є потреба у розробці проектних завдань, які відповідатимуть на запити сучасних школярів і мотивуватимуть їх до навчання, зокрема і до вивчення української літератури.

\section{Список літератури:}

1. Бібік Н.М., Ващенко Л.С., Локшина О.І., Овчарук О.В. Компетентнісний підхід у сучасній освіті: світовий досвід та українські перспективи (бібліотека з освітньої політики) : колективна монографія / заг. ред. О.В. Овчарук. Київ, 2004. 112 с.

2. Василевська Л.С. Проектна діяльність методиста як засіб удосконалення професійної майстерності педагогів. Наукові записки Ніжинського державного університету іл. Миколи Гоголя. Психолого-педагогічні науки. 2012. № 6. С. 1-6.

3. Гончаренко С. Український педагогічний словник / гол. ред. С. Головко. Київ, 1997. 373 с.

4. Єрмаков I.Г. Компетентнісний потенціал проектної діяльності. Школа. 2006. № 5. С. 5-11.

5. Ісаєва Г.М. Метод проектів - ефективна технологія навчання учнів сучасної школи. Метод проектів: mpaдииї, перспективи, життєві результати : практико-зорієнтований збірник / керів. авт. кол. С.М. Шевцова, наук. керів. і ред. І.Г. Єрмаков. Київ, 2003. С. 207-211.

6. Коберник О.М. Проективна технологія: можливості застосування в освіті. Педагогіка вищої та середньої школи. Кривий Ріг, 2012. Вип. 36. С. 15-18.

7. Кобиляцький Л.С. Управління проектами : навч. посіб. Київ, 2002. 200 с.

8. Кримський С.Б. Метод проектів: традиції, перспективи, життеві результати. Проект $і$ проектування в сучасній иивілізації. Київ, 2003. С. 6-15.

9. Тищенко Н. Проектна технологія як засіб розвитку мотивації учнів у процесі навчання української мови. Украӥнська література в загальноосвітній школі. Київ, 2015. № 2. С. 42-48.

10. Цимбалару А.Д. Семантика понятійного апарату проблеми педагогічного проектування. Нова педагогічна дулка. Рівне, 2009. № 3. С. 30-35.

11. Чеховська Л.Й. Проектне навчання на уроках української літератури у середній школі : наук.-метод. посіб. Запоріжжя, 2010. $263 \mathrm{c.}$

12. Енциклопедія сучасної України. URL: http://esu.com.ua/search_articles.php?id=1449 (дата звернення: 13.08.2020).

\section{References:}

1. Bibik N.M., Vashhenko L.S., Lokshyna O.I., Ovcharuk O.V. (2004) Kompetentnisnyj pidxid u suchasnij osviti: svitovyj dosvid ta ukrayinski perspektyvy: Biblioteka z osvitnoyi polityky [Competence approach in modern education: world experience and Ukrainian perspectives: Library on educational policy]. Kyiv: K.I.S. (in Ukrainian)

2. Vasylevska L.S. (2012) Proektna diyalnist metodysta yak zasib udoskonalennya profesijnoyi majsternosti pedagogiv [Project activity of a methodologist as a means of improving the professional skills of teachers]. Scientific notes of Nizhyn State University of Nikolai Gogol. Psychological and pedagogical sciences, vol. 6, pp. 1-6.

3. Goncharenko S. (1997) Ukrayinskyj pedagogichnyj slovnyk [Ukrainian pedagogical dictionary]. Kyiv: Lybid. (in Ukrainian)

4. Yermakov I.G. (2006) Kompetentnisnyj potencial suchasnoyi osvity: proektno-texnologichni zasady [Competence potential of modern education: design and technological principles]. School, vol. 5, pp. 5-11.

5. Isayeva G.M. (2003) Metod proektiv - efektyvna texnologiya navchannya uchniv su-chasnoyi shkoly [The project method is an effective technology for teaching modern school students]. Project method: traditions, perspectives, life results. Kyiv: Departament. (in Ukrainian)

6. Kobernyk O.M. (2012) Proektyvna texnologiya: mozhlyvosti zastosuvannya v osviti [Projective technology: possibilities of application in education]. Higher and secondary school pedagogy, pp. 15-18.

7. Kobylyaczkyj L.S. (2002) Upravlinnya proektamy [Project management]. Kyiv: MAUP. (in Ukrainian)

8. Krymskyj S.B. (2003) Metod proektiv: tradytsiyi, perspektyvy, zhyttyevi rezultaty. [Project method: traditions, prospects, life results]. Proekt i proektuvannya v suchasniy tsyvilizatsiyi [Project and design in modern civilization]. Kyiv: Departament, pp. 6-15.

9. Tishchenko N. (2015) Proektna tekhnolohiya yak zasib rozvytku motyvatsiyi uchniv u protsesi navchannya ukrayins'koyi movy [Project technology as a means of developing students' motivation in the process of learning the Ukrainian language]. Ukrainian literature in secondary school, vol. 2, pp. 42-48.

10. Cymbalaru A.D. (2009) Semantyka ponyatiynoho aparatu problemy pedahohichnoho proektuvannya [Semantics of the conceptual apparatus of the problem of pedagogical design]. Nova pedahohichna dumka [New pedagogical thought], vol. 3 , pp. 30-35.

11. Chexovska L.J. (2010) Proektne navchannya na urokakh ukrayinskoyi literatury u seredniy shkoli [Project teaching in lessons of Ukrainian literature in secondary school]. Zaporizhzhya. (in Ukrainian)

12. Encyclopedia of modern Ukraine. URL: http://esu.com.ua/search_articles.php?id=1449 